\title{
Policies, rewards, and opportunities: Antecedents of employee retention
}

\author{
Rabia Asif ${ }^{1}$, Sabahat Nisar ${ }^{2}$ \\ ${ }^{1}$ Department of Management Sciences, Lahore College for Women University, Lahore, Pakistan, ${ }^{2}$ PhD Scholar, Lahore \\ School of Accountancy and Finance, University of Lahore, Pakistan
}

\section{AbSTRaCT}

Purpose: Human resources are possibly among the most critical resources of any organization. The Human Resource Department is responsible to both attract and retain talented employees within the organization. As retention of 'skilled employees' is linked with organizational success, we aim to reveal the antecedents of employee retention by carefully analyzing the impact of various HR practices, such as career development opportunities, work-life policies, good supervision, and rewards. Design/Methodology: We collected data, using primary sources through self-administered questionnaire survey. Additionally, we employed multiple regression analysis to test research hypotheses. Findings: We specifically sought to determine the variables that have a significant influence on employee retention. Thus, our findings do support the positive influence of rewards and work-life balance on employee's retention, while supervisor's support and career opportunities do not promote employee retention, especially within private schools in Pakistan. Limitations: Our research was limited in scope, as we obtained the data primarily from the teaching staff, working in private schools from Lahore. Secondly, besides our findings, there may be other antecedents affecting the employees' work-life balance, vis a vis their retention. Originality: Since, the academic staffs at secondary school level play an important role in influencing the moral character of students, a job security would provide them with an edge to incorporate healthy practices in shaping the students' future life. Thus, this study contributes to retention practices of private schools' employees, which would ensure a secured working environment leading to better performance.

Key words: Antecedents, good supervision and support, HR practices, opportunities, retention, work-life policies

\section{INTRODUCTION}

Employee turnover is a global phenomenon; almost all organizations go through the problem of turnover intention (Janjhua et al., 2016). Turnover can either be positive or negative in terms of organizational success (Kossivi et al., 2016). In today's world of intense competition, organizations are facing lots of problems regarding turnover rate (Shokunbi, 2016). Excessive turnover is often considered a symptom of fundamental problems about the organization's working environment. However, at times, turnover may be triggered by employees' career objectives, whereby they prefer to move to other organizations (Rothmann et al., 2019). Nevertheless, most

\footnotetext{
*Corresponding author:

Rabia Asif, Department of Management Sciences, Lahore College for Women University, Lahore, Pakistan. E-mail: rabia_pms@hotmail.com
}

Received: November 04, 2021; Accepted: November 30, 2021

DOI: $10.18843 / \mathrm{ijcms} / \mathrm{v} 13 \mathrm{i} 1 / 03$ 
times, the turnover intention is triggered by employees feeling dissatisfied with existing organizational practices and policies, like promotions, remuneration, learning opportunities, among others, which compel them to explore other alternatives (Mobley et al., 1979: Fouche et al., 2017). Briefly, it may be stated that employees' dissatisfaction is the root cause of high turnover rates (Akila, 2012).

With the passage of time, Human Resource Management (HRM) practices are gaining more importance, with employees being considered as critical assets of an organization (Anis et al., 2011). Hence, there is a need to foster employee demands, which actually boost their motivation level to avoid turnover (Enu-Kwesi et al., 2014). Historically, the concept of retention gained importance in the early 1970s with a rise of SMEs as competitive employers, leading to the provision of sustainable employment opportunities (Coff, 1997). This factor accelerated to the ascendancy in employee's mobility from job and voluntary job changes. Consequently, organizations began to face the effect of the rise in voluntary employee's turnover. Further, the power in the authoritarian "status quo" working relationship shifted from employer toward the employee; so there was a need to develop a matching management tool, manifested in the form of 'employee retention' (Connell and Phillip, 2003). The very concept of employee retention is intrinsically attached with the existence of an organization (Raikes and Vernier, 2004). An employer today is expected to know how to retain its prolific employees (Shoaib et al., 2009). Hence, it may be stated that the costs of employee turnover are significantly affecting an organization's bottom line today (Sullivan, 2009).

Previous studies revealed the role of different antecedents in retaining employees. Factors that have an undeviating influence on employee retention include career opportunities, work environment, and work-life balance (Cappelli, 2000). Cole (2000) stated that employees would be loyal with institutions, where they feel pride, and thereby work to their fullest potential. Retaining employees must thereby be the top priority for organizations, because at times only the earnings or the position doesn't suffice for employees to choose to continue their jobs (Ashraf et al., 2016).

Possibly the first and the foremost thing that enables an employee to stay on in an organization is 'job satisfaction', triggered through 'job contentment'. Job contentment refers to optimistic feelings that employees have toward their jobs (Feldman, 1985). Job satisfaction on the other hand, is a multifaceted phenomenon that is affected by various other variables, besides 'contentment'. It includes the workplace environment, pay, communication, and organizational commitment (Vidal et al., 2007; Lane et al., 2010). However, if organizations nurture their employees with factors that satisfy them, no one would leave the institution. Employees demand a good salary package, development opportunities, supervisor's support, good work environment, job security, etc. Gardner et al. (2004) found that salary is considered an imperative motivating factor for employee retention strategy. There is a close and positive relation between growth opportunities and job satisfaction, which in turn, helps in retaining employees (Pergamit and Veum, 1999). Miller et al. (2001) stated that employees feel secure at work, when the workplace environment provides them a sense of comfort and belonging.

This study contributes to the ongoing debate on the issue of employee retention by exploring employee retention strategies in private sector schools in Lahore, Pakistan. We look to explore employee retention by incorporating important explanatory variables, such as career opportunities, work-life practices and policies, rewards, and good supervision and support. Specifically, through the private schools of Lahore, we aim to understand how they try to retain their employees, using different antecedents, and how these antecedents actually go on to influence employee retention. Notably, the focus of study has been restricted to private schools, because of the unavailability of formal HR and administration department in public schools. Public schools are monitored by the country's education department, which makes general rules for all the schools. Another specific study will be required to cover the turnover in public sector, to obtain concise results. However, if we include both the sectors, it may widen the scope of study and result in biased outcome. Both the sectors have separate reasons of turnover and cannot be covered under one study. Hence, to achieve the correct and unbiased results, this study will only cover the private sector. Second, to limit the scope of study to private schools is due to high turnover rate in private schools therefore, it is important to explore the retention at secondary school level.

Private schools in Pakistan have emerged as a result of the deregulation of prevailing education system. In Punjab province for instance, private schools are currently operating within a highly competitive environment; this signals some form of management success in terms of enhancing employee retention for the sake of competitive advantage. Still heavy workload and low 
remuneration are considered as major issues which are creating disappointment among the employees of these private schools. The situation is getting worse due to poor working environment and lack of financial advantage for the employees of the private schools. The adverse effect of these operating issues results in brain drain of skilled employees in many of the private schools, leading to raising concerns about human resource retention. Hence, the problem of employee retention is getting worse in public schools which the school management must be resolved to ensure quality teaching.

This study will help the stakeholders to better understand the importance of employee retention in private schools and to focus on those antecedents that help to retain employees. Hence, it would enable many private institutions to identify the major reasons that need to be used in retaining employees through better knowledge of inspirational aspects toward improving our education system (Holtom and Darabi, 2018).

\section{OBJECTIVES OF THE STUDY}

Need of the hour is to extend the knowledge regarding how employees will stick to their jobs and which motivational factors play a key role in retaining them? The major aims of the study are as follows:

- To ascertain the influence of work-life policies, growth opportunities, rewards, and supervisor's support on employee retention

- To highlight the most important determinant that plays a key role in retaining employees

- To find out the importance of retention in private institutions.

\section{THEORETICAL DEVELOPMENT}

Work-life policies are a broader term that covers different aspects, but this research covers a few of them, such as working environment, job security, and standard working hours. These aspects have a positive effect on employee retention. They may be termed as the primary factors behind employees' satisfaction and retention. Additionally, job flexibility is another key factor in employee retention. Previous researches have shown that greater the access of work-life policies, including flexibility at work, the greater would be the organizational commitment from employees (Grover and Crooker, 1995). Hence, we posit:

$H_{1}$ : Increased work-life policies have a significant impact on employee retention.
Rewards (monetary and non-monetary) both are essential for employee retention. Employers need to both understand and appreciate that employees need motivation for their efforts; thus, they should be motivated by rewards that could include incentives in salary and/or recognition. Rewards boost the motivation level; and thus, it may be affirmed that an organization's reward system does greatly influence employees' performance and retention (Bamberger et al., 2014; MacDuffie, 1995). Hence, we posit:

$\mathrm{H}_{2}$ : Increased rewards have a positive significant impact on employee retention.

Employees cannot reach to their fullest potential without their supervisor's support. Employees need motivation from their supervisors. Supervisor's support is the greatest strength to retain employees. Supervisors should develop good relation with employees that will influence employee retention (Fatima, 2011). A good supervisor is considered very effective in reducing employee's turnover. If there is a good relationship between employees and the supervisor, then the employees will never leave their jobs and if the relationship is not satisfactory, then employees will go for some new opportunity for sure. Hence, we posit:

$H_{3}$ : Increased supervisor support results into higher employee retention.

Career growth opportunities are always helpful in retaining employees. If employees are provided with opportunities that help them in their career growth, they would definitely stay. Prince (2005) argued that employees want growth opportunities to move up in their career. Thus, one of the key aspects in employee retention is investment on employees' training and career development (Messmer, 2000). Organizations must invest on training and development opportunities for employees.

Summarily, it may be affirmed that both career development, along with training and learning opportunities do provide important outcomes for both parties (i.e. employer \& employee); hence, we posit:

$H_{4}$ : Increased growth opportunities results into higher employee retention.

\section{MATERIALS AND METHODS}

\section{Participants}

The main focus of the study was to find out how much the private schools are capable in retaining in their employees using different determinants, and how these determinants 
actually influence employee retention? Teachers working in private schools in Lahore, Pakistan were the participants of this study. Specifically, we chose six private schools for data collection through convenience sampling. The schools include Bloomfield Hall School, Resource Academia, City School, Lahore Grammar School, Beacon House School, and Linderhof Lahore School System. Notably, we chose to restrict ourselves to private schools because of high turnover rates as the employees decide to move from one organization to another if their promises and expectations are not fulfilled or for their career objective too.

\section{Reliability Analysis}

Before approaching the teachers of the schools (mentioned earlier), we conducted a pilot study with 30 respondents. The questionnaires herein were randomly filled by teachers working in private schools. On the basis of those responses, we effectively verified the reliability of the main questionnaire. Further, to ensure reliability, we also adopted the Cronbach's alpha technique, as it represents a coefficient of consistency specifically meant to determine reliability. The instrument is said to be reliable if the coefficient alpha proves to be more than $60 \%$ (Cronbach, 1951). Typically, alphas of 0.6 or greater are retained for analysis (Table 1). Through SPSS reliability of whole instrument is checked which is 0.889 which means that the questionnaire is strongly reliable and further studies can be done with the same instrument.

\section{Procedures}

We distributed about 400 questionnaires across these six schools; out of the 400 questionnaires floated, we got 350 responses, out which, we had to reject 25 as they were incomplete. Hence, the response rate was $(325 / 400=$ $81.25 \%$ ), which is sufficient to continue with the collected data.

\section{Measures}

The structured questionnaire on employee retention was constructed based on our observations from extant literature. Shoaib et al. (2009) had examined the influence of supervisors' support, rewards, career opportunities, work-life policies, and work environment on retention of employees in the telecom sector of Pakistan. The purpose of collecting data through questionnaires is that to gather direct feedback from the respondents with convenience and within short time period. The structured questionnaire which is used in this research includes some demographic information along with 32 questions. The questions were based on each variable's dimensions, that is,

- Employee retention (ER): Job promotion, job satisfaction, timely feedback, optimistic thinking, and professional experience.

- Career opportunities (CO): Providing opportunities to improve interpersonal skills, providing training for delivering lectures, and training workshops.

- Work-life polices (WL): Comfortable work environment, standard working hours, job security, and good job description.

- Rewards (RW): Recognition of work, attractive salary packages, bonuses, increased motivation levels, and appreciation for employees' performance.

- Good supervision and support (GS): Freedom to share ideas, listening suggestions, motivating employees, timely and smooth communication, positive attitude of supervisors, trust, and good relationship, considering employees suggestions.

Based on the selected variables, the regression equation of the study is framed as follows:

$$
\mathrm{ER}=\alpha+\beta_{1} \mathrm{CO}+\beta_{2} \mathrm{WL}+\beta_{3} \mathrm{RW}+\beta_{4} \mathrm{GS}+€
$$

\section{Descriptive Analysis}

The tables given below show the distribution of demographic information.

In Table 2, out of 325 employees, the percentage of women in was $89.2 \%$, while men were only $10.8 \%$. This could be because of high turnover, as many a time women have to leave their job after getting married or due to family pressures. Similarly, the concentration of single employees was $42 \%$ while married represented $58 \%$. About $39.1 \%$ belonged to $20-30$ age category, highest $40.3 \%$ belonged to $30-40$ category. About $12 \%$ of employees were those who had 1 year or less than 1-year experience with the school. $36.9 \%$ had $2-5$ years of experience, while about $56 \%$ possessed Masters' degree, $23.7 \%$ were graduates and only $16.3 \%$ were MS/M.Phil.

\section{Correlation Analysis}

The Pearson correlation results are explained in Table 3 . From the table, it is clear that the highest correlation exists between work-life policies and employee retention, that is, 0.344 and it is significant at 0.01 level. However, correlation among rewards, supervisor's support, growth opportunities, and employee retention are $0.175,0.184$, and 0.111 , respectively. The private schools will flourish 
if employee retention would be increased by practicing independent variables more appropriately.

\section{Regression Analysis}

Regression analysis is one to find out the effect of independent variables on the dependent variable and to study their relationships (Table 4). The first table in the regression analysis is labeled as "model summary." It gives us the measures of how well our model fits, and how well our predictor (i.e. employee retention) is able to predict the independent variables. The value of adjusted R-square is 0.13 . It means that $13 \%$ of the variance in employee retention can be explained by work-life policies and rewards. Table 5 shows the regression estimates. Using stepwise regression, the first model considers only one predictor variable that is, work-life policies with $\mathrm{R}$ square value $11.8 \%$. However, the second model includes two predictor variables, that is, work-life policies and rewards with $\mathrm{R}$ square value $13 \%$. Reaming variable shows insignificant values therefore omitted from the model.

\section{Hypothesis 01}

Hypothesis 01 stated that increase in work-life policies will have a positive significant effect on employee retention. It means that more the work-life policies in an organization, more would the employees want to be retained. This statement is supported as shown by the results, that is, $\mathrm{r}=$ 0.344 means that correlation is significant up to 0.01 level. The B value for work-life policies is 0.551 , which means that WLP has a $55.1 \%$ influence on employee retention. The table also showed the $t$ value, that is, 6.065 , it means that it is significant up to 0.01 level. Hence, our results proved the predicted hypothesis; hence, we accept the alternative hypothesis (HI).

\section{Hypothesis 02}

Hypothesis 02 stated that increased rewards would have a positive and significant effect on employee retention. It means that the more rewards are given to employees, more would they be willing to be retained. The statement is supported as the correlation is significant up to 0.01 level, that is, 0.175 . The B value of rewards is 0.135 , which showed that rewards have $13.5 \%$ influence on staff retention. The table also shows the t value, that is, 2.083 and is significant up to the level of 0.05 . Hence, even in this case, the results proved the prediction, and we thereby accept the alternative hypothesis (H2).

\section{Hypothesis 03}

The third hypothesis stated that increase in supervisor's support would have a positive and significant effect on employee retention. It means that the more a supervisor supports an employee, more would be the employee's intent to remain in the organization. In terms of results, that is, $r=0.184$ means that relationship is significant up to 0.01 level. Further, from the results, it is revealed that the $\mathrm{p}$ value is greater than the significance level, which means that

\begin{tabular}{lc}
\multicolumn{2}{c}{ Table 1: Reliability statistics } \\
Cronbach's alpha & N of items \\
\hline 0.889 & 30 \\
\hline
\end{tabular}

Table 2: Demographic analysis

Frequency

Percentage

\begin{tabular}{|c|c|c|}
\hline \multirow{2}{*}{\multicolumn{3}{|c|}{ Gender }} \\
\hline & & \\
\hline Male & 35 & 10.8 \\
\hline Female & 290 & 89.2 \\
\hline Total & 325 & 100.0 \\
\hline \multicolumn{3}{|l|}{ Marital Status } \\
\hline Single & 136 & 41.8 \\
\hline Married & 189 & 58.2 \\
\hline Total & 325 & 100.0 \\
\hline \multicolumn{3}{|l|}{ Age } \\
\hline $20-30$ & 127 & 39.1 \\
\hline $30-40$ & 131 & 40.3 \\
\hline $40-50$ & 47 & 14.5 \\
\hline 50 and above & 20 & 6.2 \\
\hline Total & 325 & 100.0 \\
\hline \multicolumn{3}{|c|}{ Years of Experience } \\
\hline 1 year or less & 42 & 12.9 \\
\hline $2-5$ & 120 & 36.9 \\
\hline $5-10$ & 88 & 27.1 \\
\hline $10-20$ & 66 & 20.3 \\
\hline $20-30$ & 9 & 2.8 \\
\hline Total & 325 & 100.0 \\
\hline \multicolumn{3}{|l|}{ Education Level } \\
\hline Bachelors & 77 & 23.7 \\
\hline Masters & 2 & 56 \\
\hline MS/M.Phil & 53 & 16.3 \\
\hline Other & 13 & 4 \\
\hline Total & 325 & 100.0 \\
\hline
\end{tabular}


increased supervisor's support does not result into higher employee retention, and thereby the null hypothesis (Ho) is accepted.

\section{Hypothesis 04}

Hypothesis 4 stated that increased growth opportunities have a positive and significant effect on employee retention. In other words, it means that the more the opportunities employees are given to grow, more would they be interested in staying back. This is reflected by the outcome, that is, $r=0.175$ meaning that the relationship is significant up to 0.05 level. This variable is excluded as the results are not significant, which means that the increased growth opportunities do not necessarily result in higher employee retention. Hence, the null hypothesis HO is accepted. The variables of hypotheses 3 and 4 are rejected as they are not statistically significant. These two variables,

\section{Table 3: Pearson's correlation}

\begin{tabular}{lccccc} 
& ER & CO & WL & RW & GS \\
\hline ER & 1 & & & & \\
CO & $0.111^{*}$ & 1 & & & \\
WL & $0.344^{\star *}$ & $0.185^{\star *}$ & 1 & & \\
RW & $0.175^{\star *}$ & $0.477^{\star *}$ & $0.199^{\star *}$ & 1 & \\
GS & $0.184^{\star *}$ & $0.625^{\star *}$ & $0.387^{\star *}$ & $0.678^{\star *}$ & 1 \\
\hline
\end{tabular}

${ }^{* *}$ Correlation is significant at the 0.01 level (two tailed).

${ }^{*}$ Correlation is significant at the 0.05 level (two tailed)

\begin{tabular}{ccccc} 
Model & R & R square & $\begin{array}{c}\text { Adjusted } \\
\text { R square }\end{array}$ & $\begin{array}{c}\text { Std. error of } \\
\text { the estimate }\end{array}$ \\
\hline 1 & $0.344^{\mathrm{a}}$ & 0.118 & 0.115 & 3.26 \\
2 & $0.360^{\mathrm{b}}$ & 0.130 & 0.124 & 3.24 \\
\hline
\end{tabular}

that is, growth opportunities and supervisor's support do not show any impact on employee retention in the private school's setting. Table 6 summarizes the overall conclusion regarding the acceptance of stated hypotheses.

\section{DISCUSSION}

The study has contributed both theoretically and methodologically to the literature. The wide purpose of the study as stated earlier was to identify the determinants of employee retention. Similarly, the study sought to determine those variables that have a noteworthy positive influence on employee retention in the private schools. The findings of the study would possibly help the school's management in formulating effectual retention approach using the suitable variables. In addition, the study would also help in bridging the gap in literature, and advance the boundary of knowledge.

Four hypotheses were generated from the literature review. Out of four, two alternative and null hypotheses each are accepted. We found that work-life policies and rewards act as important motivational variables that have a positive and significant influence on employee retention in private sector institutions. The results were supported by the previous studies, for example, supportive work-life policies can be the reason in retaining employees for longer time period (Richman et al., 2008). Monetary rewards significantly increase employee retention (Pillay, 2009).

The foremost rationale behind this study was to explore the impact of rewards, work-life policies, supervisors' support, and career opportunities on employee retention. The results

\begin{tabular}{|c|c|c|c|c|c|}
\hline \multicolumn{6}{|c|}{ Table 5: Coefficients } \\
\hline \multirow[t]{2}{*}{ Model } & \multicolumn{2}{|c|}{$\begin{array}{l}\text { Unstandardized } \\
\text { coefficients }\end{array}$} & Standardized coefficients & $\mathbf{T}$ & Sig. \\
\hline & B & Std. error & Beta & & \\
\hline \multicolumn{6}{|l|}{1} \\
\hline Constant & 29.1 & 1.966 & & 14.851 & 0.000 \\
\hline WLP & 0.589 & 0.089 & 0.344 & 6.578 & 0.000 \\
\hline \multicolumn{6}{|l|}{2} \\
\hline Constant & 27.17 & 2.183 & & 12.448 & 0.000 \\
\hline WLP & 0.551 & 0.091 & 0.322 & 6.065 & $0.000^{* *}$ \\
\hline $\mathrm{R}$ & 0.135 & 0.065 & 0.111 & 2.083 & $0.038^{\star}$ \\
\hline
\end{tabular}

**Significant at the 0.01 level. *Significant at the 0.05 level 
of this study show that work-life policies have a positive significant effect on retaining private schools' staff. It means that work-life policies are the foremost determinant of employee retention in private schools. Institutions need to monitor the level of work-life policies to strengthen the relationship between employees and the institution.

The results also found that rewards have a positive significant influence on employee retention. An enhanced reward system within an institution/organization does enhance job commitment (Boyd and Sutherland, 2006). It means that increased rewards result into higher employee retention in private sector schools. It also means that most employees feel valued whenever they receive rewards. In fact, Kreitner and Kinicki (2006) stated that rewards are one of the most important factors that create job commitment.

Furthermore, the results also affirm that supervisor's support does not necessarily help in retaining employees. Specifically, we noted that there is no substantial relationship between employee retention and supervisor's support. From the third hypothesis, it is revealed that supervisor's support does not result into higher employee retention in private schools setting. Thus, it is not proved to be the influential variable in retaining employees. However, descriptive analysis showed that supervisor's support does play a key role in retaining employees, as it has the highest mean value amongst the independent variables. Additionally, the results showed that career opportunities do not influence employee retention among private schools' employees. There doesn't seem to be any association between career opportunities and employee retention. From hypothesis 4, it is revealed that career opportunities do not result into higher employee retention in private schools setting.

\section{Limitation and Directions of Future Research}

\section{Table 6: Summary of results}

\begin{tabular}{lcc} 
Hypothesis & Results & Supported \\
\hline $\mathrm{H}_{1}$ : Increase in work-life policies & $\mathrm{r}=0.344$ & Yes \\
will have a strong influence on & $P=0.000$ & \\
employee retention & & \\
$\begin{array}{l}\mathrm{H}_{2} \text { : Increased rewards have a } \\
\text { positive significant impact on }\end{array}$ & $\mathrm{r}=0.175$ & Yes \\
employee retention. & & \\
$\mathrm{H}_{3}$ : Increased growth & $\mathrm{r}=0.038$ & \\
$\begin{array}{l}\text { opportunities results into higher } \\
\text { employee retention }\end{array}$ & $P=0.764$ & \\
$\begin{array}{l}\mathrm{H}_{4}: \text { Increase in supervisor's } \\
\text { support results into higher }\end{array}$ & $\mathrm{r}=0.184$ & \\
employee retention & $P=0.474$ & \\
\hline
\end{tabular}

The researcher is limited in scope of research work as the current study is limited only to obtain data from the teaching staff working in private schools from Lahore region. Further, there are other antecedents within the employee work-life that may have specified impact on employee retention; these antecedents must be incorporated in future research.

\section{CONCLUSION}

Employee retention is a phenomenon which is perceived to negatively impact the success of the organization. Previous attempts in this regard have shown divergent antecedents of employee retention with respect to the nature of the environment. This study contributes to the ongoing debate by seeking to determine those variables that have a noteworthy influence on employee's retention in private schools of Pakistan. To find how an organization can retain their employees, this study examined different antecedents, which could be helpful to organizations in retaining their employees. The antecedents used included rewards, worklife policies, good supervision and support, and career opportunities. The findings support the positive influence of rewards and work-life balance on employee's retention, while supervisor's support and career opportunities do not promote employees retention in private schools in Pakistan.

\section{AUTHORS' CONTRIBUTIONS}

The authors state that the submitted work is an original work. All the articles or journals referred to have been duly cited in text and in references attached. The authors further state that they have no issue in regard to publication of the article under the Indian Journal of Commerce and Management. The authors declare that they have no known competing financial interests or personal relationships that could have appeared to influence the work reported in this paper.

\section{FINANCIAL SUPPORT}

The authors have to meet all expenditures themselves. No funding source is available.

\section{ACKNOWLEDGMENTS}

Authors duly acknowledge the support of the institutions for giving us the opportunity to complete the research 
and providing us with all necessary facilities regarding respondents and space for survey.

\section{CONFLICTS OF INTEREST}

There are no conflicts of interest.

\section{REFERENCES}

Akila, R. (2012). A study on employee retention among executives at BGR, Energy systems LTD, Chennai. International Journal of Marketing, Financial Services and Management Research, 1(9), 18-32.

Anis, A., Nasir, A., \& Safwan, N. (2011). Employee retention relationship to training and development: A compensation perspective. African Journal of Business Management, 5(7), 2679-2685.

Ashraf, M., Ahmad, N., \& Haider, S. (2016). Antecedents of turnover intentions: A study of karachi business schools. Journal of Business Studies, 12(1), 139-156.

Bamberger, P.A., Biron, M., \& Meshoulam, I. (2014). Human Resource Strategy: Formulation, Implementation, and Impact. London, United Kingdom: Routledge.

Boyd, G., \& Sutherland, M. (2006). Obtaining employee commitment to living the brand of the organization. African Journal of Business Management, 37(1), 9-20.

Cappelli, P. (2000). A market-driven approach to retaining talent. Harvard Business Review, 78(1), 103-11.

Coff, R. W. (1997). Human assets and management dilemmas: Coping with hazards on the road to resourcebased theory. Academy of Management Journal, 22, 374-402.

Cole, C. L. (2000). Building loyalty. Workforce, 79(8), 45.

Connell, A. O., \& Phillip, J. J. (2003). Managing Employee Retention: A Strategic Approach. Oxford, Butterworth: Heinemann.

Cronbach, L. J. (1951). Coefficient alpha and the internal structure of tests. Psychometrika, 16(3), 297-334.

Enu-Kwesi, F., Koomson, F., Segbenya, M., \& Annan-Prah, E. C. (2014). Determinants of employee retention in Ghana, Kumasi. European Journal of Contemporary Economics and Management, 1, 81.

Fatima, H. (2011). Does employee retention affect organizational competence? Industrial Engineering Letters, 1(1), 24-39.

Feldman, D. C. (1985). Managing Individual and Group Behavior in Organizations. New York, United States: McGraw-Hill Book Co.

Fouche, E., Rothmann, S. S., \& van der Vyver, C. (2017). Antecedents and outcomes of meaningful work among school teachers. SA Journal of Industrial Psychology, 43(1), 1-10.

Gardner, D. G., Dyne, L., \& Pierce, J. L. (2004). The effects of pay level on organization-based self-esteem and performance: A field study. Journal of Occupational and Organizational Psychology, 77(3), 307-322.

Grover, S. L., \& Crooker, K. J. (1995). Who appreciates family-responsive human resource policies: The impact of family-friendly policies on the organizational attachment of parents and non-parents. Personnel Psychology, 48(2), 271-288.

Holtom, B. C., \& Darabi, T. (2018). Job embeddedness theory as a tool for improving employee retention. In: Psychology of Retention. Berlin, Germany: Springer, p. 95-117.

Janjhua, Y., Chaudhary, R., \& Sharma, R. (2016). An empirical study on antecedents of employee retention and turnover intentions of employees. International Journal of Research in Business Management, 4(5), 1-10.

Kossivi, B., Xu, M., \& Kalgora, B. (2016). Study on determining factors of employee retention. Open Journal of Social Sciences, 4, 261-268.

Kreitner, R., \& Kinicki, A. (2006). Organizational Behavior. New York: McGraw Hill.

Kyriakidou, O., \& Ozbilgin, M. (2004). Individuals, organizations and careers: A relational perspective. Career Development International, 9(1), 7-11.

Lane, K. A., Esser, J., Holte, B., \& McCusker, M. A. (2010). A study of nurse faculty job satisfaction in community colleges in Florida. Teaching and Learning in Nursing, 5(1), 16-26.

MacDuffie, J. P. (1995). Human resource bundles and manufacturing performance: Organizational logic and flexible production systems in the world auto industry. Industrial and Labor Relations Review, 48(2), 197-221.

Messmer, M. (2000). Orientation programs can be key to employee retention. Strategic Finance, 81(8), 12-14.

Miller, N. G., Erickson, A., \& Yust, B. L. (2001). Sense of place in the workplace: The relationship between personal objects and job satisfaction and motivation. Journal of Interior Design, 27(1), 35-44.

Mobley, W. H., Griffeth, R. W., Hand, H. H., \& Meglino, B. M. (1979). Review and conceptual analysis of the employee turnover process. Psychological Bulletin, 86(3), 493.

Otis, N., \& Pelletier, L. G. (2005). A motivational model of daily hassles, physical symptoms, and future work intentions among police officers. Journal of Applied Social Psychology, 35(10), 2193-2214.

Pergamit, M. R., \& Veum, J. R. (1999). What is a promotion? ILR Review, 52(4), 581-601. 
Pillay, R. (2009). Work satisfaction of professional nurses in South Africa: A comparative analysis of the public and private sectors. Human Resources for Health, 7(1), $1-10$.

Prince, B. J. (2005). Career-focused employee transfer processes. Career Development International, 10(4), 293-309.

Raikes, L., \& Vernier, J. F. (2004). Rewarding and Retaining Key Talent: Are You Ready for the Recovery. Stamford, Connecticut, United States: Tower Perrin.

Richman, A. L., Civian, J. T., Shannon, L. L., Jeffrey Hill, E., \& Brennan, R. T. (2008). The relationship of perceived flexibility, supportive work-life policies, and use of formal flexible arrangements and occasional flexibility to employee engagement and expected retention. Community Work and Family, 11(2), 183-197.

Rothmann, S., Redelinghuys, K., \& Botha, E. (2019). Workplace flourishing: Measurement, antecedents and outcomes. SA Journal of Industrial Psychology, 45(1), 1-11.
Shoaib, M., Noor, A., Tirmizi, S. R., \& Bashir, S. (2009). Determinants of employee retention in telecom sector of pakistan. Vol. 14. In: Proceedings of the $2^{\text {nd }} C B R C$, Lahore, Pakistan, p. 1-18.

Shokunbi, O. A. (2016). Antecedents to employee engagement: A qualitative study of 28 senior secondary school teachers in Nigeria. International Journal of Scientific and Research Publications, 6(6), 128-135.

Sullivan, J. (2009). The Ideal Turnover Rate, Battling Environmental Turnover. Canada: ECO, p. 1-4.

Vidal, M. E. S., Valle, R. S., \& Aragón, M. I. B. (2007). Antecedents of repatriates' job satisfaction and its influence on turnover intentions: Evidence from Spanish repatriated managers. Journal of Business Research, 60(12), 1272-1281.

Woodruffe, C. (1999). Winning the Talent War: A Strategic Approach to Attracting, Developing and Retaining the Best People. New York, United States: John Wiley and Sons. 